\title{
Mixing Xanthan Gum and Chitosan Nano Particles to Form New Coating for Maintaining Storage Life and Quality of Elmamoura Guava Fruits
}

\author{
Mohamed M. Gad ${ }^{1 *}$ and Osama A. Zagzog ${ }^{2}$ \\ ${ }^{1}$ Department of Horticulture, Faculty of Agriculture, Zagazig University, Egypt \\ ${ }^{2}$ Department of Plant Production, Faculty of Technology and Development, \\ Zagazig University, Egypt \\ *Corresponding author
}

\begin{tabular}{|c|}
\hline Keywords \\
\hline $\begin{array}{l}\text { Guava, Xanthan gum, } \\
\text { Chitosan nano } \\
\text { particles, Coating, } \\
\text { Weight loss, Fruit } \\
\text { decay, Quality } \\
\text { attributes, Storage life, } \\
\text { Shelf life, Post- } \\
\text { harvest. }\end{array}$ \\
\hline Article Info \\
\hline $\begin{array}{l}\text { Accepted: } \\
\text { 12 September } 2017 \\
\text { Available Online: } \\
10 \text { November } 2017\end{array}$ \\
\hline
\end{tabular}

\section{Introduction}

Guava (Psidium guajava L.) is an important fruit crop grown under a wide range of the tropical and subtropical regions in the world (Chopda and Barrett, 2001). Guava fruit is very perishable during storage at room temperature due to rapid ripening and deterioration, which decreases the potential for commercialization of the fruits (Samaan $e t$ al., 2012). Cold storage is not enough to preserve the quality. So, coating with thin layer film of natural materials extended fruit life under cold storage.

In many fruits, it used as alternative to natural waxes that removed during washing (Baldwin, 1994; Hagenmaier and Baker, 1994; Hagenmaier, 1998). Various compounds have been used as edible 
coatings; most of them are based on proteins, lipids or polysaccharides (Bai et al., 2003). Edible coatings are natural products and not chemically synthesized (Falcao-Rodrigues et al., 2007). Chitosan is a natural polysaccharide with a polycationic nature which has numerous applications in agriculture (Bautista-Baños et al., 2006), as an edible coating maintains fruits quality during the postharvest (Olivas and BarbosaCa'novas, 2005).

Chitosan forms a semi-permeable film that modifies the internal atmosphere, decreasing transpiration losses and preserves the fruits quality (El Ghaouth, Arul, and Ponnampalam, 1991; Olivas and Barbosa-Ca'novas, 2005).

Xanthan gum is a polysaccharide, it widely uses as a food additive and thickening agent. It produced by the fermentation of simple sugars; glucose, sucrose, or lactos (GarcíaOchoa et al., 2000).

Off flavors, that reduces the fruit quality during storage results from anaerobic respiration. It may be one of the common problems of coating from ethanol and acetaldehyde (Chen and Nussinovitch, 2000).

Using different formulation of coating materials increased wax permeability and forms a homogenous coating especially when mixed with nanoparticles materials that improves the permeability and distribution on fruit surface (Zambrano-Zaragoza et al., 2013).

The aim of this investigation is prolonging the storage life of guava fruits with high marketable quality suitable for exporting to Europe and other countries.

This may be achieved by enhancing coating material properties through mixing xanthan with chitosan nanoparticles and examine the effects on guava fruits during cold storage and shelf life periods.

\section{Materials and Methods}

\section{Plant material}

This study was carried out during the 2015 and 2016 seasons on Elmamoura guava fruits (Psidium guajava L.). The fruits were harvested from a private orchard (the trees were 10 -year-old, grown in sandy soil at $5 \times 5$ meters apart and received the standard horticultural practices adopted in this area) at El-Tahrer north district, El-Bihira Governorate, Egypt.

Fruits at mature-green or breaker stage were picked on the same date in mid-September in both seasons, using small clippers, packed in carton boxes, then transported directly to Post-Harvest Laboratory in Horticulture Department, Faculty of Agriculture, Zagazig University, Egypt. Chosen fruits sorted to be healthy, free of physiological and pathological disorders and uniform in color and size. Finally, it was washed using tap water then air-dried before treatment.

The experimental design was factorial (4 treatments $\times 5$ weeks) in a complete randomized design, in three replicates, each replicate contained 30 fruits.

The fruits were coated with $1 \%$ xanthan gum, mixing $1 \%$ xanthan gum with $0.2 \%$ chitosan nano particles (CHNs), mixing $1 \%$ xanthan gum with $0.4 \%$ CHNs and control fruits (without coating). 1\% of tween 80 added to xanthan gum and $\mathrm{CHNs}$ as a surfactant. All fruits packed in perforated $(0.06 \%$ of area) 20-micron thickness low-density polyethylene (LDPE) bags after coating treatments.

The fruits were stored for 2, 3, 4, 5 and 6 weeks at $8 \pm 1^{\circ} \mathrm{C}(\mathrm{RH} \sim 85-90 \%)$ in a cooler, 
thereafter held at $20 \pm 1{ }^{\circ} \mathrm{C}(\mathrm{RH} \sim 65-70 \%)$ for 6 days after cold storage to evaluate fruit marketability (shelf life).

\section{CHNs preparation and measurment}

Chitosan nano crystallite powder was synthesized by high-energy ball milling. Powder mixture was conducted in a planetary ball mill to $40 \mathrm{~h}$ using ball to powder mass ratio of $(8: 1)$. The chitosan samples were examined by X-ray diffraction using a Philips model (PW-1729) diffract meter equipped with $\mathrm{Cu} \mathrm{K} \alpha$ radiation source $(\lambda=1.541178$ $\AA$ ). Infrared spectra (FTIR) for the chitosan samples were carried out at room temperature by using a PERKIN-ELMER-1430 recording infrared spectra in the range 200 to $4000 \mathrm{~cm}-1$ (at Tanta University, Central lab.

The microstructure of the sintered samples examined using High Resolution Transmission Electron Microscope (HRTEM) model JOEL EM 2-100) according to Gad et al., 2016.

Evaluation of cold storage period treatments and shelf life effects on guava fruits were carried out through the following quality attributes:

\section{Fresh weight losses (FWL) percentage}

The fruits were weighed before cold storage to obtain the initial weight, and then weighed after each period of cold storage and shelf life. FWL were calculated as a percentage of the initial weight according to the following equation:

$$
F W L \quad \%=\frac{W i-W s}{W i} \times 100
$$

Where,

$\mathrm{Wi}=$ fruit weight at initial period, $\mathrm{Ws}=$ fruit weight at sampling period (Hazali et al., 2013; Ibrahim and Gad, 2015).

\section{Fruit decay percentage (FD \%)}

It was determined as percentage of decayed fruits by using the following equation according to Ismail et al., (2010)

Fruit decay $\%=\frac{\text { number of decayed fruits }}{\text { initial number of stored fruits }} \times 100$

\section{Fruit pulp firmness (FPF)}

It was determined on five fruits per replicate on two opposite sides of the equatorial region of the fruit after peel removal by using a Push Pull dynamometer (Model FD 101).

The values were expressed as $\left(\mathrm{g} / \mathrm{cm}^{2}\right)$ (Ibrahim and Gad, 2015).

\section{Peel color index (PCI)}

The color of each fruit was determined according to the following index: $0=100 \%$ green; $1=1-20 \%$ yellow; $2=21-40 \%$ yellow; $5=41-60 \%$ yellow; $8=61-80 \%$ yellow; $10=$ 81-100\% yellow (El-Hefnawi et al., 2008).

\section{Panel test index (PTI)}

Each replicate was judged by 5 persons who gave the score according to the following index: 4 = Excellent test; 3 = Very good test; $2=$ Good test $; 1=$ Acceptable test $; 0=$ Bad test (El-Hefnawi et al., 2008).

\section{Juice total soluble solids content (TSS \%)}

It was determined using a hand refractometer as Brix (Hazali et al., 2013 and Gad et al., 2016).

\section{Ascorbic acid (vitamin C) content}

It was determined by titration in presence of 2, 6 dichlorophenol-indophenol dye as 
indicator against $2 \%$ oxalic acid solution as substrate.

Ascorbic acid was calculated as milligrams per $100 \mathrm{ml}$ of juice (Kabasakalis et al., 2000).

\section{Juice titratable acidity}

It was determined by titrating an aliquot of juice against $0.1 \mathrm{~N} \mathrm{NaOH}$ in presence of phenolphthalein dye as indicator, the results were calculated as grams of citric acid per $100 \mathrm{ml}$ fruit juice (AOAC, 1995).

\section{Total sugars $\%$}

It was determined by using the method of Smith et al., (1956) and calculated as $\mathrm{g}$ glucose per $100 \mathrm{~g}$ fresh weight.

All chemicals used in this work obtained from El-Gomhouria for Trading Chemicals and Medical Appliances, El-Sawah, El-Amiria, Cairo, Egypt.

\section{Statistical analysis}

Statistical analysis was conducted for the collected data using the Statistic 9 (2008) according to (Snedecor and Cochran, 1989). Data subjected to the ANOVA and a factorial in a complete randomized design, was used (Steel and Torrie, 1980). Means were tested using LSD test $(\mathrm{P}<0.05)$ to investigate the significant differences between coating treatments, weeks of storage and their interaction.

\section{Results and Discussion}

In both seasons, fruit decay (\%) was significantly decreased by coating fruit surface with mixing xanthan and CHNs compared to control (Tables 1 and 2). The same trend was obtained in fruit held for six days at $20^{\circ} \mathrm{C}$ after cold storage. No decay observed till the fourth week of storage, then appeared at the fifth week and reached maximum after six weeks of storage. Similar results were obtained in fruit held for six days at $20^{\circ} \mathrm{C}$. Control fruits after six weeks of cold storage gave the highest percentage of decayed fruits as well as after six days at $20^{\circ} \mathrm{C}$.

In the first season, fresh weight loss (FWL) was significantly decreased with increasing the concentrations of CHNs. While no significant differences between all treatments were detected in the second season and after six days at $20^{\circ} \mathrm{C}$ in both seasons. Almost no FWL through the first three weeks of cold storage was observed, and then increased to get the highest values at the end of storage period. Fruits held for six days at $20^{\circ} \mathrm{C}$, was not clear any trend of FWL when the time advanced. Fruits of guava coated with $1 \%$ xanthan gave the highest in FWL at the end of cold storage in the first season. The interaction between treatments and periods was insignificantly effects on FWL in the second season and fruit held for six days at $20^{\circ} \mathrm{C}$ in both seasons.

The fruits coated with $1 \%$ xanthan and $1 \%$ xanthan $+0.2 \%$ CHNs maintained the highest fruit pulp firmness (FPF) in the first and second seasons. As well as, fruits held for six days at $20^{\circ} \mathrm{C}$ gave the same trend. The FPF decreased with the advance in cold storage period in both seasons after refrigeration and after six days at $20^{\circ} \mathrm{C}$.

Control fruit samples had the lowest (FPF 547 $\mathrm{g} / \mathrm{cm}^{2}$ ) at the end of sixth week of cold storage, while $1 \%$ xanthan after two weeks was the highest FPF $\left(897 \mathrm{~g} / \mathrm{cm}^{2}\right)$ in the two seasons. While, the interaction between treatments and storage periods had insignificant effect on FPF either in cold storage or shelf life at $20^{\circ} \mathrm{C}$ for six days. Tables 3 and 4 present the variation between xanthan only and other treatments in panel test index (PTI). The lowest PTI was 
observed in xanthan only compared with control and mixing with CHNs with different concentrations in the first and second seasons (2.9 and 3.0, respectively). As well as, xanthan or xanthan $+0.4 \%$ CHNs achieved the lowest PTI in fruit held for six days at $20^{\circ} \mathrm{C}$, where no significant differences between them in both seasons. The PTI enhanced with the advance of cold storage period or in fruit held for six days at $20^{\circ} \mathrm{C}$. Control fruits showed the highest in PTI (3.9) after six weeks of cold storage, while coating fruits with $1 \%$ xanthan showed the lowest value (2.3) after two weeks of cold storage in the first season only. The interaction between treatments and periods was insignificant in FWL after refrigerating in the second season and after six days at $20^{\circ} \mathrm{C}$ in both seasons.

Mixing CHNs with xanthan achieved the highest peel color index (PCI) (6.9 and 6.6, respectively) after refrigeration in the second season only. No significant differences were obtained in PCI between throw all treatments after refrigeration in the first season, as well as, between them after six days at $20^{\circ} \mathrm{C}$ in both seasons. PCI were increased with advancing cold storage period or in fruits held for six days at $20^{\circ} \mathrm{C}$ in both seasons. No significant differences in PCI observed in the interaction throw all treatments and cold storage periods and after six days at $20^{\circ} \mathrm{C}$ in the two seasons.

In the second season, xanthan gum at $1 \%+$ $0.2 \%$ CHNs gave the significant highest TSS compared with control. While, no significant differences were observed between all treatments in the first season and after six days at $20^{\circ} \mathrm{C}$. The TSS gradually increased with advancing cold storage period or after six days at $20^{\circ} \mathrm{C}$. No significant differences obtained between all treatments and cold storage periods and after six days at $20^{\circ} \mathrm{C}$ in both seasons. It is clear from Table 5 and 6 that, no significant differences were observed in vitamin $\mathrm{C}$ between all treatments in both seasons. After six days at $20^{\circ} \mathrm{C}$, the treatment $1 \%$ xanthan $+0.2 \%$ CHNs maintained the highest vitamin $\mathrm{C}$ compared to other treatments. While the lowest vitamin $\mathrm{C}$ came from higher concentration of CHNs $0.4 \%$.

Vitamin C was decreased gradually with the advance of cold storage periods and after six days at $20^{\circ} \mathrm{C}$ in the two seasons.

In total acidity, no significant differences was observed between all treatments, with the advance in storage period and the interaction between them after refrigeration and after six days at $20^{\circ} \mathrm{C}$ in both seasons.

Control treatment had the highest value of total sugars (12.43 and $12.55 \%$ ), while $1 \%$ xanthan $+0.4 \%$ CHNs was the lowest $(10.78$ and $10.87 \%$ ) respectively in the first and second seasons, respectively.

On the contrary, after six days at $20^{\circ} \mathrm{C}, 1 \%$ xanthan $+0.4 \%$ CHNs gave the highest total sugars (10.39 and $10.50 \%)$, while $1 \%$ xanthan was the lowest values (9.80 and 9.90\%), in the first and second seasons, respectively.

Total sugars increased with the progress of storage period from the second to fifth weeks, and then decreased in the last week and after six days at $20^{\circ} \mathrm{C}$ in both seasons.

The particle size affects the distribution of coating material, and then effects on the different fruit characteristics during storage. The coating distribution was irregular with the large sizes of particle. On the contrary, the distribution of coating in nano form was more regular and stable (Shi et al., 2011; Zambrano-Zaragoza et al., 2013). Mixing xanthan gum and CHNs decreasing the particle size and increasing coalescence of the homogenization suspension (Noriega-Peláez et al., 2011; Zambrano-Zaragoza et al., 2013). 
Table.1 Effect of mixing xanthan gum and chitosan nano particles on fruit decay percentage, fresh weight losses and fruit pulp firmness of Elmamoura guava fruits during cold storage

periods and their interaction in 2015 and 2016 seasons

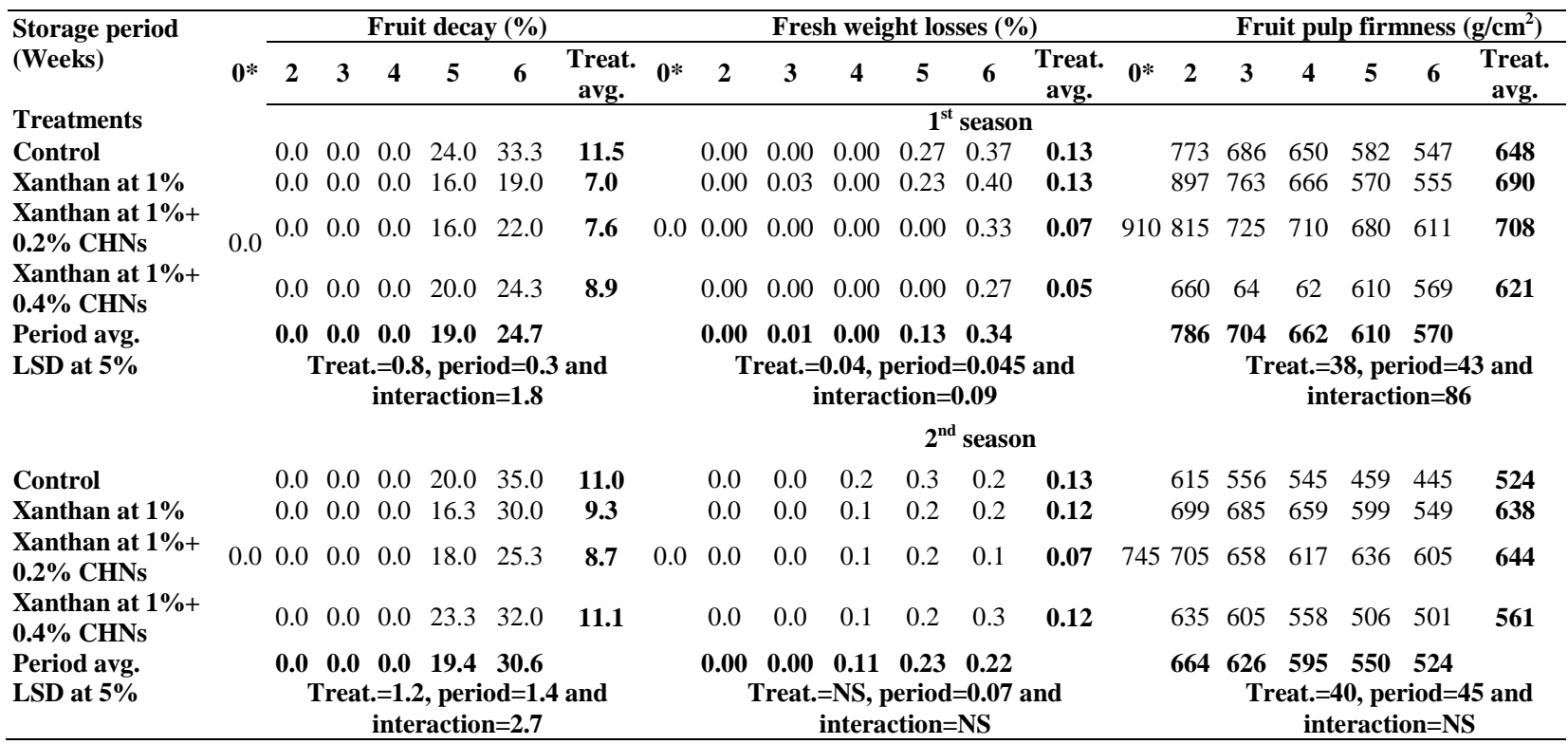

$\mathrm{CHNs}=$ chitosan nano particles, treat. $=$ treatments, avg. $=$ average, $\mathrm{NS}=$ non-significant, ${ }^{*}=$ zero time

Table.2 Effect of of mixing xanthan gum and chitosan nano particles on fruit decay percentage, fresh weight losses and fruit pulp firmness of Elmamoura guava fruits during shelf life* periods and their interaction in 2015 and 2016 seasons

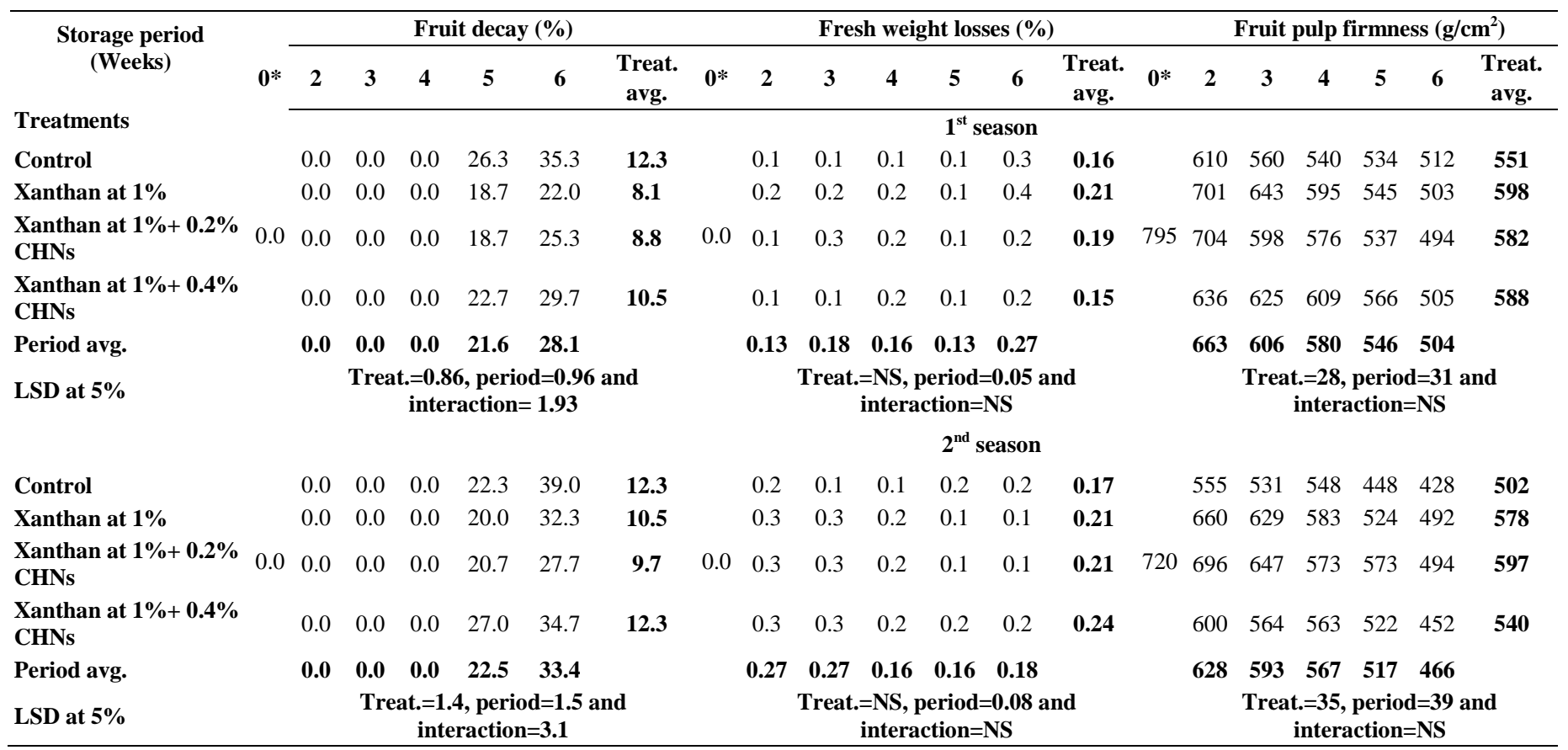

$\mathrm{CHNs}=$ chitosan nano particles, treat. $=$ treatments, avg. $=$ average, $\mathrm{NS}=$ non-significant, $*=$ zero time

*six days at $20^{\circ} \mathrm{C}$ and $60-70 \% \mathrm{RH}$ after cold storage. 
Table.3 Effect of mixing xanthan gum and chitosan nano particles on Panel test index, peel color index and Total soluble solids (TSS) of Elmamoura guava fruits during cold storage periods and their interaction in 2015 and 2016 seasons

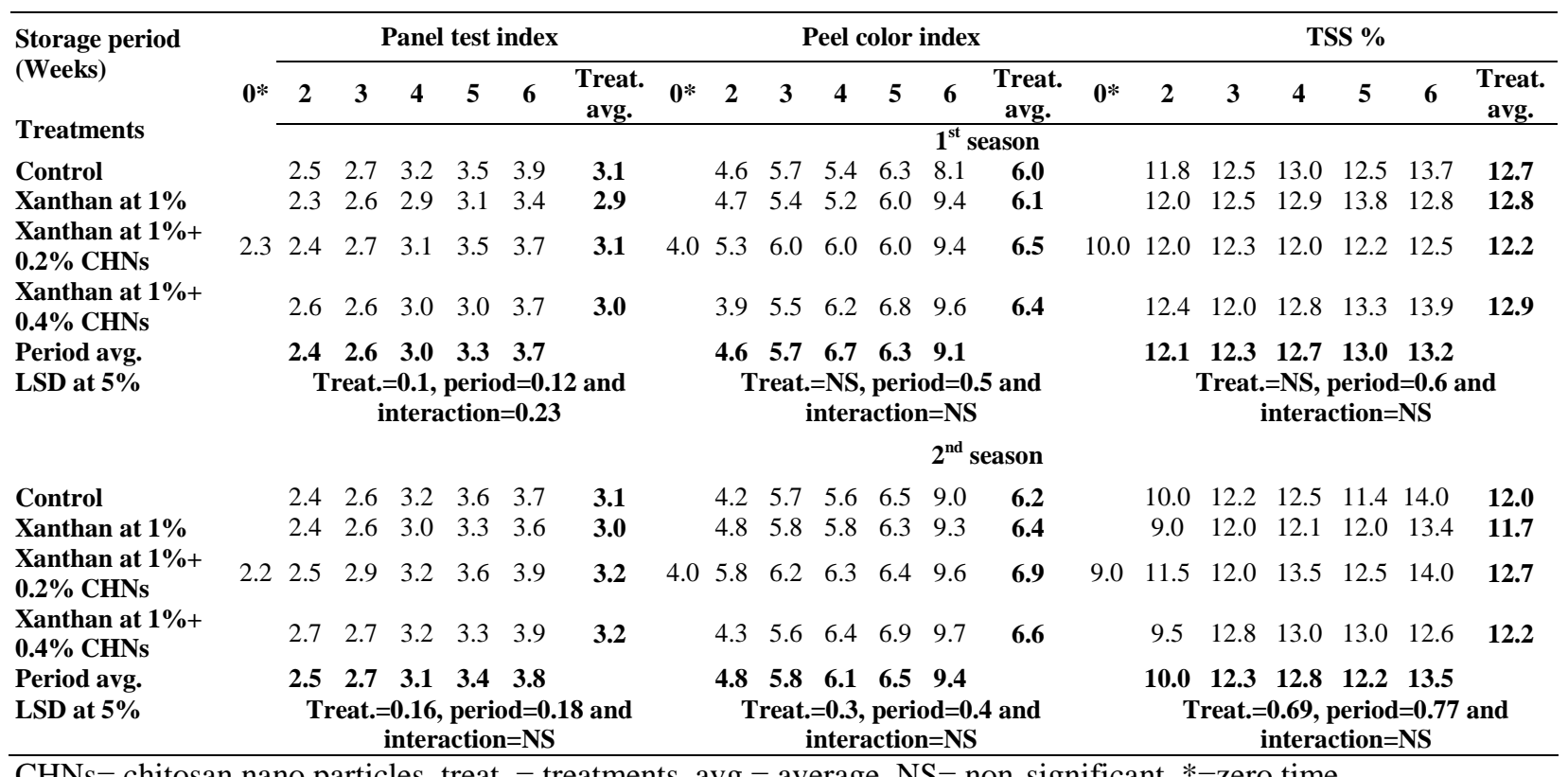

$\mathrm{CHNs}=$ chitosan nano particles, treat. $=$ treatments, avg. $=$ average, $\mathrm{NS}=$ non-significant, ${ }^{*}=$ zero time

Table.4 Effect of mixing xanthan gum and chitosan nano particles on Panel test index, peel color index and Total soluble solids (TSS) of Elmamoura guava fruits during shelf life* periods and their interaction in 2015 and 2016 seasons

\begin{tabular}{|c|c|c|c|c|c|c|c|c|c|c|c|c|c|c|c|c|c|c|c|c|c|}
\hline \multirow{3}{*}{$\begin{array}{l}\text { Storage period } \\
\text { (Weeks) }\end{array}$} & & \multicolumn{6}{|c|}{ Panel test index } & \multicolumn{8}{|c|}{ Peel color index } & \multicolumn{6}{|c|}{ TSS \% } \\
\hline & $\mathbf{0}^{*}$ & 2 & 3 & 4 & 5 & 6 & $\begin{array}{l}\text { Treat. } \\
\text { avg. }\end{array}$ & $\mathbf{0}^{*}$ & 2 & 3 & 4 & 5 & 6 & $\begin{array}{l}\text { Treat. } \\
\text { avg. }\end{array}$ & 0* & 2 & 3 & 4 & 5 & 6 & $\begin{array}{l}\text { Treat. } \\
\text { avg. }\end{array}$ \\
\hline & & & & \multicolumn{18}{|c|}{$1^{\text {st }}$ season } \\
\hline Control & & 3.2 & 3.2 & 3.5 & 3.7 & 4.0 & 3.5 & & 5.6 & 6.3 & 6.3 & 6.8 & 9.2 & 6.9 & & 12.9 & 14.1 & 13.0 & 12.4 & 13.4 & 13.2 \\
\hline Xanthan at $1 \%$ & & 2.9 & 2.9 & 3.2 & 3.2 & 3.5 & 3.1 & & 5.0 & 6.3 & 7.1 & 7.4 & 9.5 & 7.1 & & 12.2 & 12.6 & 12.2 & 13.2 & 12.6 & 12.6 \\
\hline $\begin{array}{l}\text { Xanthan at } 1 \%+ \\
0.2 \% \text { CHNs }\end{array}$ & 2.5 & 3.6 & 3.2 & 3.2 & 3.5 & 3.9 & 3.5 & 4.5 & 5.1 & 5.7 & 6.5 & 7.2 & 9.3 & 6.8 & 10.5 & 12.6 & 12.7 & 13.0 & 13.0 & 12.9 & 12.9 \\
\hline $\begin{array}{l}\text { Xanthan at } 1 \%+ \\
0.4 \% \text { CHNs }\end{array}$ & & 2.9 & 3.0 & 3.1 & 3.3 & 3.9 & 3.2 & & 5.8 & 6.3 & 7.2 & 7.1 & 9.6 & 7.2 & & 12.0 & 12.5 & 12.6 & 13.5 & 12.8 & 12.7 \\
\hline Period avg. & & 3.1 & 3.1 & 3.3 & 3.4 & 3.8 & & & 5.4 & 6.2 & 6.8 & 7.1 & 9.4 & & & 12.4 & 13.0 & 12.7 & 13.0 & 12.9 & \\
\hline \multirow{2}{*}{\multicolumn{2}{|c|}{ LSD at $5 \%$}} & \multicolumn{6}{|c|}{$\begin{array}{c}\text { Treat. }=0.16, \text { period }=0.18 \text { and } \\
\text { interaction }=N S\end{array}$} & \multicolumn{8}{|c|}{$\begin{array}{c}\text { Treat. }=\mathrm{NS}, \text { period }=0.4 \text { and } \\
\text { interaction }=\mathrm{NS}\end{array}$} & \multicolumn{6}{|c|}{$\begin{array}{c}\text { Treat. }=\mathrm{NS}, \text { period }=\mathrm{NS} \text { and } \\
\text { interaction }=\mathrm{NS}\end{array}$} \\
\hline & & & & & \multicolumn{17}{|c|}{$2^{\text {nd }}$ season } \\
\hline Control & & 3.3 & 3.3 & 3.6 & 3.9 & 4.0 & 3.6 & & 6.2 & 6.4 & 6.5 & 6.9 & 9.3 & 7.06 & & 11.5 & 12.3 & 12.0 & 12.5 & $12.2 \mathrm{a}$ & 12.1 \\
\hline Xanthan at $1 \%$ & & 3.0 & 3.1 & 3.3 & 3.4 & 3.6 & 3.3 & & 4.6 & 6.2 & 6.9 & 7.5 & 8.3 & 6.71 & & 12.0 & 13.9 & 13.0 & 12.2 & $12.8 \mathrm{a}$ & 12.6 \\
\hline $\begin{array}{l}\text { Xanthan at } 1 \%+ \\
0.2 \% \text { CHNs }\end{array}$ & 2.4 & 3.7 & 3.4 & 3.5 & 3.7 & 4.0 & 3.7 & 4.2 & 4.2 & 4.6 & 5.2 & 6.5 & 8.7 & 5.83 & 10.0 & 12.0 & 12.0 & 12.0 & 12.6 & $13.0 \mathrm{a}$ & 12.3 \\
\hline $\begin{array}{l}\text { Xanthan at } 1 \%+ \\
0.4 \% \text { CHNs }\end{array}$ & & 2.9 & 3.0 & 3.2 & 3.4 & 4.0 & 3.3 & & 5.3 & 6.3 & 6.8 & 7.8 & 9.3 & 7.11 & & 11.0 & 12.0 & 12.6 & 13.0 & $13.5 \mathrm{a}$ & 12.4 \\
\hline Period avg. & & 3.24 & 3.20 & 3.39 & 3.60 & 3.91 & & & 5.07 & 5.88 & 6.36 & 7.19 & 8.89 & & & & 12.6 & 12.4 & 12.6 & 12.9 & \\
\hline LSD at $5 \%$ & & \multicolumn{6}{|c|}{$\begin{array}{c}\text { Treat. }=0.15 \text {, period }=0.17 \text { and } \\
\text { interaction }=\mathrm{NS}\end{array}$} & \multicolumn{8}{|c|}{$\begin{array}{c}\text { Treat. }=0.49, \text { period }=0.55 \text { and } \\
\text { interaction }=\mathrm{NS}\end{array}$} & \multicolumn{6}{|c|}{$\begin{array}{c}\text { Treat. }=\mathrm{NS}, \text { period }=0.79 \text { and } \\
\text { interaction }=\mathrm{NS}\end{array}$} \\
\hline
\end{tabular}

$\mathrm{CHNs}=$ chitosan nano particles, treat. $=$ treatments, avg.= average, $\mathrm{NS}=$ non-significant, $*=$ zero time *six days at $20^{\circ} \mathrm{C}$ and $60-70 \% \mathrm{RH}$ after cold storage. 
Table.5 Effect of mixing xanthan gum and chitosan nano particles on vitamin $\mathrm{C}$, total acidity and Total sugars of Elmamoura guava fruits during cold storage periods and their interaction in 2015 and 2016 seasons

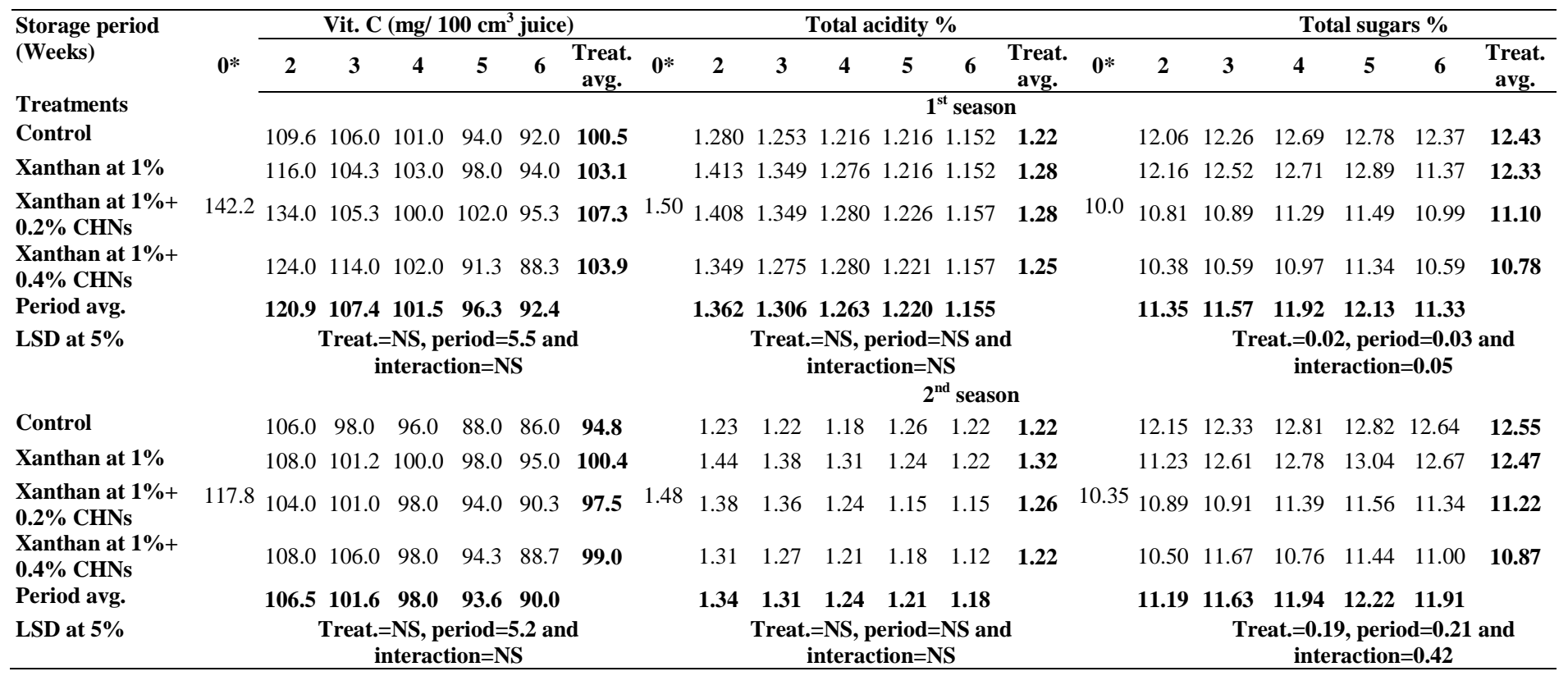

$\mathrm{CHNs}=$ chitosan nano particles, treat. $=$ treatments, avg. $=$ average, $\mathrm{NS}=$ non-significant, $*=$ zero time

Table.6 Effect of mixing xanthan gum and chitosan nano particles on vitamin $\mathrm{C}$, total acidity and Total sugars of Elmamoura guava fruits during shelf life* periods and their interaction in 2015 and 2016 seasons

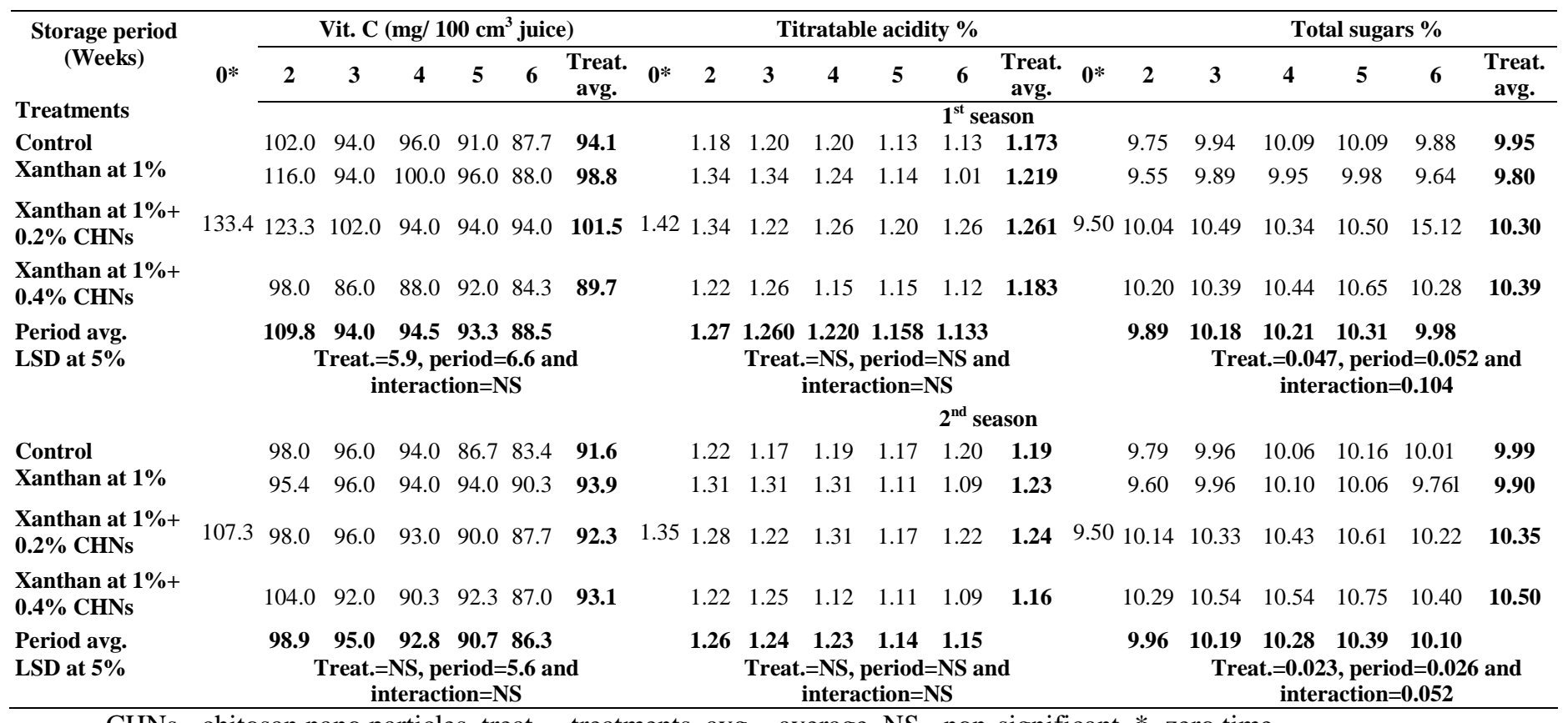

$\mathrm{CHNs}=$ chitosan nano particles, treat. $=$ treatments, avg. $=$ average, $\mathrm{NS}=$ non-significant, ${ }^{*}=$ zero time

$*$ six days at $20^{\circ} \mathrm{C}$ and $60-70 \% \mathrm{RH}$ after cold storage. 
Xanthan gum mixed with two different concentrations of CHNs $(0.2$ and $0.4 \%)$ were tested on the different characteristics of guava fruits compared with xanthan gum and control fruits without any coating materials.

Xanthan and xanthan $+0.2 \%$ CHNs had the lowest decay percent may be due to the activation of fruit self-defense resistance to fungi, enhancing the activity of enzymes, which helps in killing fungi. Chitosan nano particles interfere with negatively charged residues of macromolecules exposed on the fungal cell surface that leads to the leakage of intracellular electrolytes and proteinaceous constituents. Chitosan nano particles able to bind with microbial DNA, leading to inhibition of the mRNA and protein synthesis. It forms gas-impermeable coating that inhibits fungal growth (Zakrzewska et al., 2005; Bautista-Baños et al., 2006; Meng et al., 2008; Gad et al., 2016; Khaliq et al., 2017 and Romanazzi et al., 2017). The effect of chitosan coatings that inhibited decay symptoms in various fruits, including peach (Ma et al., 2013), strawberry (Gol et al., 2013), table grapes (Gao et al., 2013) mango (Khaliq et al., 2017) and peach (Gad et al., 2016).

Shriveling and dehydration is an indicator to water loss from fruit surface due to transpiration, which reduces fruit quality in the postharvest (Pérez-Gago et al., 2010; Khaliq et al., 2017; Romanazzi et al., 2017). In this work, xanthan gum coating used to form a semipermeable fruit surface film, as a gas exchange barrier, which did not reduce the water transport, so that, mixing $\mathrm{CHNs}$ into the coating creates a lipophilic surface, which acting as a protective barrier against water (Khaliq et al., 2017 and Romanazzi et al., 2017). The limitation of water vapor exchange observed in these results with the increase of CHNs concentration. The hydrophilic nature of the gum, which absorbs water and removes it through the ambient, may explain this effect (García-Ochoa et al., 2000). The reduction in weight loss by using chitosan have been observed in some fruits as strawberry, litchi, dragon fruit, peach, mango and guava (Gol et al., 2013; Lin et al., 2011; Ali et al., 2013; Gad et al., 2016; Khaliq et al., 2017; Romanazzi et al.,2017).

Fruit softening positively related to ripening process. The activity of hydrolytic enzymes increased with ripening causes loss of fruit hardness (Razzaq et al., 2014; Gad et al., 2016). Xanthan and low concentration of CHNs maintained firmness more than control and high concentration of CHNs. Control treatment enhanced ripening compared to other treatments, so, it lose firmness. The deterioration in fruits treated with high concentration of CHNs caused reduction in firmness. These results are Compatible with Xing et al., (2011) on sweet pepper; Zhou et al., (2011) on pear; Ma et al., (2013) and Gad et al., (2016) on peach; Khaliq et al., (2017) on mango and Romanazzi et al., (2017) on guava.

It is clear from the results that mixing xanthan with CHNs enhanced PTI. The coating film created by chitosan inhibits $\mathrm{CO}_{2}$ and ethylene production from the commodity (Gad et al., 2016). Using wax and gum in coating may results anaerobic respiration, which results ethanol and acetaldehyde responsible of off flavor (Chen and Nussinovitch, 2000). Wax formulations with different materials may enhance coating distribution regularity on fruit surface (Zambrano-Zaragoza et al., 2013), which maintains better taste for extended periods. It is associated with maturity, ripening and color change. After shelf life, mixing xanthan with $0.2 \% \mathrm{CHNs}$ showed a reduction in color change. Delay in chlorophyll degradation is the main reason in delay color change. The delay in color change reported by Jain et al., 2003 and Espinoza- 
Zamora et al., (2010). The deterioration in fruit surface resulted from high concentration of CHNs increased chlorophyll degradation by enhancing fruit ripening. The degradation in Vitamin $\mathrm{C}$ also associated with ripening and fruit deterioration, as the CHNs $0.2 \%$ maintained the highest vitamin $\mathrm{C}$, while $0.4 \%$ was the lowest. This was in line with Gad et al., 2016 on peach. The reduction in TSS in fruits coated with xanthan clarified by the elevation in respiration rate, which consumed sugars (Espinoza-Zamora et al., 2010; Zambrano-Zaragoza et al., 2013). The delay of ripening in $\mathrm{CHNs}$ treatments may be the main reason for the decrease of total sugars in these treatments compared with control and xanthan.

Coatings form a semi-permeable barrier to water vapor and gas exchange, leading to weight loss reduction, respiration rate modification, and senescence delay of coated produce (Hagenmaier and Baker, 1994; Nisperos-Carriedo, 1994; Olivas et al., 2008).

However, the effect of the wax formulation on the fruit itself is often ignored (Petracek, Hagenmaier, and Dou, 1999). Wellrecognized effects of waxing include modified gas exchange of the peel, which often results in high levels of ethanol and acetaldehyde. At high levels, these volatiles are considered off-flavors and reduce fruit quality (Sinclair, 1984).

Wax permeability can be increased by using formulations with constituents that increase permeability or by promoting the development of small holes and cracks in the wax and puncturing the fruit (Petracek et al., 1999). A recent study reported that the inclusion of xanthan gum, a non-gelling hydrocolloid, in a traditional wax coating creates disturbances in the ordered structure of the wax. Because of the "imperfect" coating, fruit respiration is less disturbed and lower levels (relative to commercial coatings) of ethanol and acetaldehyde accumulate in the fruit (Chen and Nussinovitch, 2000).

Edible coatings generate a modified atmosphere by creating a semi-permeable barrier against $\mathrm{O}_{2}, \mathrm{CO}_{2}$, moisture and solute movement, thus reducing respiration, water loss and oxidation reaction rates (MartínezRomero et al., 2006).

Such coatings tend to overly restrict the exchange of $\mathrm{O}_{2}$ and $\mathrm{CO}_{2}$ between atmosphere and fruit to the extent that internal $\mathrm{O}_{2}$ concentration becomes too low to sufficiently support aerobic respiration, resulting in high values of internal ethanol, acetaldehyde and internal $\mathrm{CO}_{2}$. Similar effects have also been observed with citrus fruit stored under controlled atmosphere conditions (Hatton and Spalding, 1990; Ke and Kader, 1990).

Mixing xanthan gum with $0.2 \% \mathrm{CHNs}$ as a coating to guava fruit cv. ELmamoura decreased decay, color change, maintained fruit firmness, good taste, vitamin $\mathrm{C}$ and reduced total sugars compared with xanthan gum or high concentration of CHNs. The mix of xanthan gum with $0.2 \%$ CHNs coating enhanced overall quality of guava fruits during extended cold storage and shelf life periods.

\section{References}

AOAC. 1995. Official Methods of Analysis of AOAC International, $6^{\text {th }}$ Ed., Vol II, Association of Official Agricultural Chemists, Gaithersburg, MD.

Bautista-Baños, S., Hernandez-Lauzardo, A.N., Velazquez-Del Valle, M.G., Hernández-López, M., Barka, E.A., Bosquez-Molina, E., Wilson, C. 2006. Chitosan as a potential natural compound to control pre and postharvest diseases of horticultural 
commodities. Crop Protection 25: 108118.

Chen, S., and A. Nussinovitch, 2000. The role of xanthan gum in traditional coatings of easy peelers. Food Hydrocolloids, 14(4), 319-326.

Chopda, C. A. and Barrett, D. M. 2001. Optimization of guava juice and powder production. J. Food Process. Press., 25: 411-417.

El-Hefnawi, S.M., Safaa, A. Nomier, A.S.A. Hassan, and M.M. Gad 2008. Effect of packaging during cold storage period on guava fruits cv. El-Mamoura. Egypt. J. of Appl. Sci., 23 (3): 186-212.

Espinoza-Zamora, J., Baez-Sañudo, R., Saucedo-Veloz, C., and Mercado-Silva, E. 2010. Effect of application of waxes with vegetable oil and sucrose on the quality of Mexican guava cv. "Media China". Acta Hort., 849, 393-400.

Gad, M.M.; Zagzog, O.A. and Hemeda, O.M. 2016. Development of Nano-Chitosan Edible Coating for Peach Fruits Cv. Desert Red. Inter. J. of Environment 5(4): 43:55.

Gao, P., Zhu, Z., and Zhang, P. 2013. Effects of chitosan-glucose complex coating on postharvest quality and shelf life of table grapes. Carbohydrate Polymers, 95, 371-378.

García-Ochoa, F; Santos, V.E; Casas, J.A; Gómez, E 2000. Xanthan gum: production, recovery, and properties. Biotechnology Advances. 18(7): 549579.

Gol, N. B., Patel, P. R., and Rao, T. V. R. 2013. Improvement of quality and shelflife of strawberries with edible coatings enriched with chitosan. Postharvest Boil. and Tech., 85,185-195.

Hazali, N., A.R.A. Tajudin, N.M. Nor, M. Ibrahim and M.N.A. Yahya, 2013. Physicochemical Characteristics of Belimbing Dayak (Baccaurea angulata) Juice Beverages. European Inter. J. of
Sci. and Tech., 2: 203-210.

Ibrahim, M.M. and Gad, M.M. 2015. The Relationship between Harvest Date and Storage Life of Washington Navel Orange Fruits. Middle East J. Appl. Sci. 5(4): 1247-1256. http://www.curresweb. com/mejas/mejas_oct-dec-2015.html

Ismail, O. M., El-Moniem, E. A. A. A., AbdAllah, A. S. E., and Rl-Naggar, M. A. A. (2010). Influence of some postharvest treatments on guava fruits. Agric. Biol. JN Am, 1(6), 130-31.

Jain, N., Dhawan, K., Malhotra, S., and Singh, R. 2003. Biochemistry of fruit ripening of guava (Psidium guajava $\mathrm{L}$.): Compositional and enzymatic changes. Plant Foods for Human Nutrition, 58(4), 309-315.

Kabasakalis, V., Siopidou, D., and Moshatou, E. 2000. Ascorbic acid content of commercial fruit juices and its rate of loss upon storage. Food chemistry, 70(3), 325-328.

Khaliq, G., un Nisa, M., Ramzan, M., and Koondhar, N. 2017. Textural Properties and Enzyme Activity of Mango (Mangifera indica L.) Fruit Coated with Chitosan during Storage. Journal of Agricultural Studies, 5(2), 32-50.

Ma, Z., Yang, L., Yan, H., Kennedy, J. F., and Meng, X. 2013. Chitosan and oligochitosan enhance the resistance of peach fruit to brown rot. Carbohydrate Polymers, 94(1), 272-277.

Meng, X. H., Li, B. Q., Liu, J., and Tian, S. P. 2008. Physiological responses and quality attributes of table grape fruit to chitosan preharvest spray and postharvest coating during storage. Food Chemistry, 106, 501-508.

Noriega-Peláez, E. K., Mendoza-Muñoz, N., Ganem-Quintanar, A., and QuintanarGuerrero, D. 2011. Optimization of the emulsification and solvent displacement method for the preparation of solid lipid nanoparticles. Drug Development and 
Industrial Pharmacy, 37(2), 160-166.

Pérez-Gago, M. B., González-Aguilar, G. A., and Olivas, G. I. 2010. Edible coatings for fruits and vegetables. Stewart Postharvest Review, 6(3), 1-14.

Romanazzi, G., Feliziani, E., Baños, S. B., and Sivakumar, D. 2017. Shelf life extension of fresh fruit and vegetables by chitosan treatment. Critical Reviews in Food Science and Nutrition, 57(3), 579-601.

Samaan, L. G., Iraqi, M. A., Lo'ay, A. A., and Serag, T. A. 2012. Treatments to increase storability and marketability of guava (Psidium guajava L.) Fruits. J. Plant Prod., Mans. Univ, 3(5), 857-876.

Shi, A., Li, D., Wang, L., Li, B., and Adhikari, B. 2011. Preparation of starch-based nanoparticles through high-pressure homogenization and mini emulsion cross-linking: Influence of various process parameters on particle size and stability. Carbohydrate Polymers, 83(4), 1604-1610.

Snedecor, G.W. and W.G. Cochran, 1989. Statistical methods, 8thEdn. Ames: Iowa State Univ, Press Iowa.

Steel, R.G. and J.H. Torrie, 1980. Principles and procedures of statistics. Me-Graw
Hill Book Co. Inc., NY, USA, 633.

Xing, Y., Li, X., Xu, Q., Yun, J., Lu, Y., and

Tang, Y. 2011. Effects of chitosan coating enriched with cinnamon oil on qualitative properties of sweet pepper (Capsicum annuum L.). Food Chemistry, 124, 1443-1450.

Zakrzewska, A., Boorsma, A., Brul, S., Hellingwerf, K. J., and Klis, F. M. 2005. Transcriptional response of Saccharomyces to the plasma membrane-perturbing compound chitosan. Eukaryot Cell, 4, 703-715.

Zambrano-Zaragoza, M. L., Mercado-Silva, E., Ramirez-Zamorano, P., CornejoVillegas, M. A., Gutiérrez-Cortez, E., and Quintanar-Guerrero, D. 2013. Use of solid lipid nanoparticles (SLNs) in edible coatings to increase guava (Psidium guajava L.) shelf-life. Food Research International, 51(2), 946-953.

Zhou, R., Li, Y., Yan, L., and Xie, J. 2011. Effect of edible coatings on enzymes, cell-membrane integrity, and cell-wall constituents in relation to brittleness and firmness of huanghua pears (Pyrus pyrifolia Nakai, cv. Huanghua) during storage. Food Chemistry, 124, 569-575.

\section{How to cite this article:}

Mohamed M. Gad and Osama A. Zagzog. 2017. Mixing Xanthan Gum and Chitosan Nano Particles to Form New Coating for Maintaining Storage Life and Quality of Elmamoura Guava Fruits. Int.J.Curr.Microbiol.App.Sci. 6(11): 1582-1593.

doi: https://doi.org/10.20546/ijcmas.2017.611.190 